\title{
Efeitos do tripolifosfato de sódio sobre as características microbiológicas, físico-químicas e vida-de-prateleira em lingüiç̧a frescal de frango*
}

\author{
ANELISE MARÇAL PÉREZ DE QUEIROZ
}

\author{
Guiomar Pedro Bergmann (Orientador - UFRGS)
}

Banca: Erna Vongt de Jong (UFRGS), Neila Silvia Pereira dos Santos Richards (UFSM), César Augusto Marchionatto Avancini (UFRGS).

Neste trabalho foram analisados os efeitos da adição de $0,125 \%, 0,25 \%, 0,375 \%$ e $0,5 \%$ de tripolifosfato de sódio sobre as contagens microbiológicas de Coliformes Totais, Escherichia coli, Salmonella spp., Staphylococcus aureus, Clostridium sulfito redutores, microrganismos mesófilos aeróbios, psicrotróficos aeróbios, nas características físico-químicas de oxidação lipídica e pH em lingüiças frescais de carne de frango, armazenadas sob refrigeração a $5^{\circ} \mathrm{C}$ nos dias $0,8,15$ e 22 . O tripolifosfato de sódio não aumentou a segurança microbiológica das lingüiças de frango, pois verificou-se aumento progressivo nas contagens das bactérias presentes, como mesófilos aeróbios e psicrotróficos aeróbios não demonstrando diferença significativa com relação ao tratamento aplicado. Para os coliformes totais evidenciou-se variação nas contagens dos mesmos, no decorrer do experimento, não apresentando correlação com as concentrações de tripolifosfato de sódio adicionadas nas lingüiças de frango. Para os demais microrganismos pesquisados os resultados encontrados nas amostras no dia 0 foram: para Salmonella spp. ausência em 25g das amostras, Staphylococcus aureus $<1,0 \times 10^{3} \mathrm{UFC} / \mathrm{g}$, Clostridium sulfito redutor $<1,0 \times 10^{3}$ UFC/g, portanto, apresentaram-se dentro do padrão exigido pela legislação para todas as amostras de lingüiças. As lingüiças frescais de frango adicionadas de $0,5 \%$ de tripolifosfato de sódio apresentaram valores de TBA mais baixos que os demais tratamentos e que o grupo controle, porém este resultado não foi significativamente diferente. Com relação aos dias de análises, estes revelaram diferença significativa para os números de TBA. Os valores foram de 0,93 = dia 0;1,39= dia 8; 4,09 = dia 15 e de 3,18 = dia 22, inicialmente os números de TBA foram baixos, os quais, apresentaram aumento progressivo ao longo da vida-de-prateleira das lingüiças, exceto nos tratamentos com 0,25\% e 0,375\% de tripolifosfato de sódio que apresentaram decréscimo destes números do dia 15 para o dia 22. Os valores do $\mathrm{pH}$ apresentaram diferença significativa para os dias de análise, tais como: dia $0=6,09$; dia $8=6,25$; dia $15=6,30$; dia $22=6,47$, estes valores demonstraram aumento do $\mathrm{pH}$ durante a vida-de-prateleira das amostras. Não houve diferença significativa entre os distintos tratamentos, porém evidenciou-se que os valores do $\mathrm{pH}$ dos tratamentos com adição de $0,5 \%$ de tripolifosfato de sódio apresentaram-se mais elevados do que os do grupo controle e também dos demais tratamentos. O tripolifosfato de sódio em diferentes concentrações não agiu prolongando a vida-de-prateleira das lingüiças frescais de frango.

Descritores: Lingüiça de frango, tripolifosfato de sódio, vida-de-prateleira, oxidação lipídica, análise microbiológica.

Apresentada: 27 março 2006

"Dissertação de Mestrado n. 432 (Especialidade: Inspeção e Tecnologia de Produtos de Origem Animal). 86f. Programa de Pós-graduação em Ciências Veterinárias [www.ufrgs.br/ppgcv], Faculdade de Veterinária, Universidade Federal do Rio Grande do Sul (UFRGS), Porto Alegre, RS/Brasil. CORRESPONDÊNCIA: A.M.P. Queiroz [anelisequeiroz@bol.com.br]. 


\title{
Effects of tripolythosphate of sodium on characteristic microbiological, physical-chemistries and shelf life in chicken fresh sausage ${ }^{* *}$
}

\author{
ANELISE MARÇAL PÉREZ DE QUEIROZ
}

\author{
Guiomar Pedro Bergmann (Adviser - UFRGS)
}

Committee: Erna Vongt de Jong (UFRGS), Neila Silvia Pereira dos Santos Richards (UFSM), César Augusto Marchionatto Avancini (UFRGS).

The aim of the present study was to assess the effects of adding $0.125 \%, 0.25 \%, 0.375 \%$ and $0.5 \%$ of sodium tripolyphosphate to the microbial counts of total coliforms, Escherichia coli, Salmonella spp., Staphylococcus aureus, sulfitereducing clostridia, and aerobic mesophilic and aerobic psychrotrophic bacteria, on physical and chemical characteristics of lipid oxidation and $\mathrm{pH}$ in chicken fresh sausages stored under refrigeration at $5^{\circ} \mathrm{C}$ on days $0,8,15$ and 22 . Sodium tripolyphosphate did not increase the microbiological safety of chicken sausages, as there was a gradual increase in the count of aerobic mesophilic and aerobic psychrotrophic bacteria, with no significant difference in relation to the treatment used. Total coliform count varied throughout the experiment, with no correlation with the concentrations of sodium tripolyphosphate added to chicken sausages. The results obtained for other microorganisms on day 0 were as follows: Salmonella spp. absent in $25 \mathrm{~g}$ of samples, Staphylococcus aureus $<1.0 \times 10^{3} \mathrm{CFU} / \mathrm{g}$, sulfite-reducing clostridia $<1.0 \times 10^{3} \mathrm{CFU} / \mathrm{g}$; therefore, they were in agreement with the standards set for all sausage samples. The chicken fresh sausages that received $0.5 \%$ of sodium tripolyphosphate had lower TBA values than those under other treatments and than those in the control group; however, this result was not significantly different. The days of analysis revealed significant difference in TBA values, which amounted to 0.93 on day 0 ; 1.39 on day $8 ; 4.09$ on day 15 , and 3.18 on day 22. TBA values were low at first, but they gradually increased throughout the shelf life of sausages, except in treatments with $0.25 \%$ and $0.375 \%$ of sodium tripolyphosphate, in which they decreased between day 15 and day 22 . For the days of analysis, $\mathrm{pH}$ values were significantly different: day $0=6.09$; day $8=6.25$; day 15 $=6.30$; day $22=6.47$, having increased during the shelf life of the samples. No significant difference was observed between the different treatments, but the $\mathrm{pH}$ values for the treatments that added $0.5 \%$ of sodium tripolyphosphate were higher than those of the control group and also higher than in the other treatments. Sodium tripolyphosphate at different concentrations did not prolong the shelf life of chicken fresh sausages.

Key words: Chicken sausage, sodium tripolyphosphate, shelf life, lipid oxidation, microbiological analysis.

Presented: 27 March 2006

\footnotetext{
${ }^{* *}$ Master's Thesis \# 432 (Field: Inspection and Technology of Products of Animal Origin). 86 p. Graduated Program in Veterinary Sciences [www.ufrgs.br/ppgcv], Faculdade de Veterinária, Universidade Federal do Rio Grande do Sul (UFRGS), Porto Alegre, RS/Brazil. CORRESPONDENCE: A.M.P. Queiroz [anelisequeiroz@bol.com.br].
} 